\title{
Citing first publication
}

This article was published in the following Dove Press journal:

Clinical Ophthalmology

19 April 2012

Number of times this article has been viewed

\section{Peter A Netland}

Department of Ophthalmology, University of Virginia, Charlottesville, Virginia, VA, USA
In the interesting article about the pars plana clip (New World Medical, Rancho Cucamonga, CA) by Diaz Llopis et al, ${ }^{1}$ I noted that the authors attributed priority (first) publication about this device to a study published in $2006 .{ }^{2} \mathrm{We}$ had a publication in 2005 about the pars plana clip, ${ }^{3}$ which was not cited in the references. The authors have made a useful contribution to the literature, but missed at least one article in their literature search! In general, claims for first publication should be made with caution, perhaps including the literature search protocol that was used to support such a claim.

\section{References}

1. Diaz-Llopis M, Salom D, Garcia-Delpech S, Udaondo P, Millan JM, Arevalo JF. Efficacy and safety of the pars plana clip in the Ahmed valve device inserted via the pars plana in patients with refractory glaucoma. Clin Ophthalmol. 2010;4:411-416.

2. Schlote T, Ziemssen F, Bartz-Schmidt KU. Pars plana-modified Ahmed glaucoma valve for treatment of refractory glaucoma: a pilot study. Graefes Arch Clin Exp Ophthalmol. 2006;244:226-341.

3. Netland PA, Schuman S. Management of glaucoma drainage implant tube kink and obstruction with pars plana clip. Ophthalmic Surg Lasers Imaging. 2005;36:167-168.

Correspondence: Peter A Netland

Department of Ophthalmology,

University of Virginia, Charlottesville,

Virginia, VA, USA

Tel + I-434-982-1086

Fax + I-434-924-5180

Email pnetland@virginia.edu

Clinical Ophthalmology

\section{Publish your work in this journal}

Clinical Ophthalmology is an international, peer-reviewed journal covering all subspecialties within ophthalmology. Key topics include: Optometry; Visual science; Pharmacology and drug therapy in eye diseases; Basic Sciences; Primary and Secondary eye care; Patien Safety and Quality of Care Improvements. This journal is indexed on

Submit your manuscript here: http://www.dovepress.com/clinical-ophthalmology-journal

\section{Dovepress}

PubMed Central and CAS, and is the official journal of The Society of Clinical Ophthalmology (SCO). The manuscript management system is completely online and includes a very quick and fair peer-review system, which is all easy to use. Visit http://www.dovepress.com/ testimonials.php to read real quotes from published authors. submit your manuscript | www.dovepress.com

Dovepress

http://dx.doi.org// 0.2147/OPTH.S31043 